\title{
Inhibition of the Release of Arachidonic Acid Prevents the Development of Sarcolemmal Membrane Defects in Cultured Rat Myocardial Cells during Adenosine Triphosphate Depletion
}

\author{
Anjan Sen, Joseph C. Miller, Rolland Reynolds, James T. Willerson, L. Maximilian Buja, and Kenneth R. Chien \\ Departments of Internal Medicine (Cardiology Division) and Pathology, University of Texas \\ Health Science Center at Dallas, Dallas, Texas
}

\begin{abstract}
Previous studies have suggested that phospholipid degradation is closely associated with the development of sarcolemmal membrane injury. This study was initiated to characterize the effects of synthetic inhibitors of phospholipase activities using a cultured myocardial cell model in which arachidonic acid is liberated after treatment with the metabolic inhibitor, iodoacetate. Pretreatment with a steroidal diamine (U26,384) blocked the degradation of labeled phosphatidylcholine and the release of arachidonic acid in cultured myocardial cells during ATP depletion. Inhibition of phospholipid degradation by U26,384 prevented the development of sarcolemmal membrane defects and the release of creatine kinase from the cultured myocardial cells during ATP depletion. Pretreatment with U26,384 had no significant effect on the extent of ATP depletion after iodoacetate treatment, which indicates that the activity of this compound could not be simply ascribed to a sparing effect on ATP concentration. These results support the hypothesis that the development of sarcolemmal membrane injury and the associated loss of cell viability are causally related to progressive phospholipid degradation. In addition, these studies indicate that the release of arachidonic acid during ATP depletion is associated with the net loss of the phosphatidylcholine molecule.
\end{abstract}

\section{Introduction}

Alterations in myocardial membrane structure and function are important in the development of myocardial cell injury during ischemia. Although the biochemical mechanisms for these alterations are unknown, previous studies in an ischemic liver model have suggested that changes in the content and composition of membrane phospholipids may play an important role in the transition from reversible to irreversible cell injury $(1,2)$.

These studies in ischemic liver may have relevance to the pathogenesis of irreversible injury during myocardial ischemia. Recently, there have been several reports that the onset of irreversible injury in ischemic canine myocardium corre-

Address all correspondence to Dr. Kenneth R. Chien, Department of Medicine and Center for Molecular Genetics, University of California at San Diego, School of Medicine M-013C, La Jolla, CA 92093.

Received for publication 4 November 1987 and in revised form 7 March 1988

J. Clin. Invest.

(c) The American Society for Clinical Investigation, Inc.

$0021-9738 / 88 / 10 / 1333 / 06 \$ 2.00$

Volume 82, October 1988, 1333-1338 lates with the accumulation of free fatty acids, including arachidonic acid, a fatty acid normally present entirely in membrane phospholipid (3-6). In a cultured myocardial cell model, the progressive release of arachidonate from myocardial membrane phospholipids is closely linked to the development of sarcolemmal membrane defects, electrolyte derangements, including calcium accumulation, and the associated loss of cell viability during ATP depletion (7-9).

Although these previous studies document a temporal correlation between arachidonic acid release and the onset of irreversible cell injury, they do not necessarily indicate a causal relationship between these two events. The availability of agents that would inhibit the release of arachidonic acid from myocardial cells would allow a critical assessment of the role of phospholipid degradation in the development of irreversible injury, and might also provide insight into the biochemical mechanisms that are responsible for the liberation of arachidonic acid.

Accordingly, this study was initiated to characterize the effects of potential synthetic inhibitors of myocardial phospholipase activities, and used a cultured myocardial cell model to test compounds that inhibit the activity of phospholipases in vitro. As a result of examining the effects of several compounds, a steroidal diamine (U26,384) ${ }^{1}$ was selected for detailed analysis (Fig. 1). In these studies, evidence was obtained that U26,384 blocked the degradation of phosphatidylcholine, the accumulation of corresponding water-soluble choline-containing metabolites, and the release of arachidonic acid in cultured myocardial cells during ATP depletion. In addition, pretreatment with $\mathrm{U} 26,384$ prevented the development of sarcolemmal membrane defects and the release of creatine kinase from the cultured myocardial cells during ATP depletion. These results provide the strongest evidence thus far that the development of sarcolemmal membrane injury and the associated loss of cell viability are causally related to increased degradation of membrane phospholipids. In addition, these

1. U26,384 was developed by the Upjohn company, Kalamazoo, MI (personal communication, Dr. S. Bunting, Lipids Research) and has been shown to inhibit porcine pancreatic phospholipase $\left(\mathrm{IC}_{50}, 50 \pm 5\right.$ $\mu \mathrm{M})$, to prevent collagen-induced platelet aggregation $\left(\mathrm{IC}_{50}, 8.2 \pm 0.9\right.$ $\mu \mathrm{M}$ ), and to block the release of arachidonic acid metabolites from neutrophils. In these platelet and neutrophil studies, the inhibition of the formation of arachidonic acid metabolites was overcome by the addition of exogenous arachidonic acid, which indicates that the effect of U26,384 was directed at the level of preventing the liberation of arachidonic acid, rather than on the inhibition of the subsequent metabolism of the free arachidonic acid. Thus, the effects of U26,384 on isolated enzyme and cell systems supported the classification of U26,384 as a synthetic phospholipase inhibitor. However, these results do not preclude a concomitant effect of U26,384 on the lipid substrate. 
<smiles>COC1=CCC2=C(CCC3C2CCC2(C(C)C)C3CCCN2C)C1</smiles>

U.26384

$\mathrm{N}$-[3-(dimethylamino)propyl]-3-methoxy- $\mathrm{N}$-methyl estra 2,5(10)-dien-17 $\beta$ amine

Figure 1. Structure of the synthetic phospholipase inhibitor, U26,384.

studies indicate that the release of arachidonic acid during ATP depletion is not limited to an imbalance in fatty acid deacylation-reacylation of phospholipids, but appears to be associated with the net loss of the phosphatidylcholine molecule.

\section{Methods}

Myocardial cell cultures. Neonatal rat myocardial cells were cultured by a modification of previous methods (7-10). Whole hearts were isolated from 2-3-d-old rats and minced in a balanced salt solution containing $\mathrm{MgSO}_{4} 7 \mathrm{H}_{2} \mathrm{O}(0.2 \mathrm{~g} /$ liter $), \mathrm{NaCl}(6.8 \mathrm{~g} /$ liter $), \mathrm{KCl}(0.4 \mathrm{~g} /$ liter), $\mathrm{NaH}_{2} \mathrm{PO}_{4} \mathrm{H}_{2} \mathrm{O}$ (1.5 g/liter), glucose ( $1 \mathrm{~g} /$ liter), and Hepes (4.76 $\mathrm{g} /$ liter) at $\mathrm{pH}$ 7.5. The myocardial cells were dispersed by the addition of the balanced salt solution containing $0.06 \%$ pancreatin (Gibco Laboratories, Grand Island, NY) and $\mathbf{0 . 0 3 \%}$ collagenase type II (Worthington Biochemical Corp., Freehold, NJ), and then stirred at $37^{\circ} \mathrm{C}$. The supernatant was removed and discarded. The cells were incubated with fresh pancreatin-collagenase for $20 \mathrm{~min}$ at $37^{\circ} \mathrm{C}$, the supernatant was collected, and the cells were isolated by centrifugation in a tabletop centrifuge for $4 \mathrm{~min}$ at $1,400 \mathrm{rpm}$. The cells were resuspended in 2 $\mathrm{ml}$ of newborn calf serum (Gibco Laboratories) and kept at $37^{\circ} \mathrm{C}$. The digestion steps were repeated four times and the cell suspensions from each digestion were combined and centrifuged at $2,100 \mathrm{rpm}$ for $6 \mathrm{~min}$. The cells were resuspended in MEM $\left(1.8 \mathrm{mM} \mathrm{Ca}^{++}\right)$(Gibco Laboratories) supplemented with $10 \%$ horse serum, $5 \%$ FCS, and $1 \%$ antibiotics (penicillin $10,000 \mathrm{U} / \mathrm{ml}$ and streptomycin $10,000 \mu \mathrm{g} / \mathrm{ml}$ ), and plated for $3 \mathrm{~h}$ to allow the differential attachment of nonmyocardial cells. The myocyte-enriched suspension was transferred to culture dishes at a density of $\sim 1.5$ million cells/60-mm culture dish. Using these techniques, after $3 \mathrm{~d}$ in culture, the percentage of beating myocardial cells exceeded $85 \%$ in each preparation.
The cells reached confluency after $72 \mathrm{~h}$ and the incubation medium was replaced with fresh medium containing either $\left[{ }^{3} \mathrm{H}\right]$ arachidonate $\left(0.2 \mu \mathrm{Ci} / \mathrm{ml}\right.$ of medium) or $\left[{ }^{14} \mathrm{C}\right]$ choline $(0.2 \mu \mathrm{Ci} / \mathrm{ml}$ of medium), which was added in a minimal volume of ethanol. After a 24-h labeling period, the radioactive medium was removed and the cells were pretreated with either vehicle (control) or various concentrations of U26,384. To induce ATP depletion, the cells were incubated with iodoacetic acid $\left(0.3-1.0 \times 10^{-4} \mathrm{M}\right)$. After various time periods of exposure to the iodoacetate, the myocardial cells and extracellular medium were harvested for biochemical and electron microscopic analyses. The experiments were performed in triplicate groups of cell culture plates unless otherwise indicated.

Analytical techniques. The separation of phospholipids and free arachidonic acid was performed as previously described (1). Medium and cells were extracted for lipid analysis by the method of Bligh and Dyer (11). To separate the neutral lipids, including free fatty acids, aliquots of the lipid extracts were spotted on silica gel G TLC plates and developed with a solvent system of hexane/diethyl ether/acetic acid $(80: 20: 1.2)$. The various phospholipid species were separated by TLC using a solvent system of chloroform/methanol/acetic acid/water (75:45:10:6). The lipid spots were visualized under ultraviolet light after spraying the plate with $0.02 \%$ dichlorofluoroscein, then they were scraped directly into scintillation vials, or subsequently eluted for further lipid analyses.

ATP content (7), cellular protein content (12), creatine kinase activity (13), lipid phosphorus (7), and light and electron microscopy of cell morphology (7) were performed according to previously described methods. Statistical analysis was performed using analysis of variance and Duncan's multiple range test. Differences between groups were considered significant at $P<0.05$ (14).

\section{Results}

Effect of U26,384 on arachidonic acid release during ATP depletion. As previously reported (7), treatment of the cultured myocardial cells with iodoacetate resulted in a time-dependent release of arachidonate from membrane phospholipids (Table I). After $4 \mathrm{~h}$ of iodoacetate treatment, there was a $>16-37 \%$ decrease in radiolabeled arachidonate content of phospholipids, including decreases in phosphatidylcholine, phosphatidylethanolamine, and phosphatidylserine plus phosphatidylinositol, as compared with control plates. The decrease in $\left[{ }^{3} \mathrm{H}\right]$ arachidonate content of phospholipids was accompanied by a corresponding ninefold increase in the release of radiolabeled arachidonic acid as free fatty acid. Pretreatment of the

Table I. Effect of U26,384 on the Distribution of $\left[{ }^{3} H\right]$ Arachidonate during ATP Depletion

\begin{tabular}{|c|c|c|c|c|c|c|}
\hline Experimental groups & $\begin{array}{l}\text { Total lipid } \\
\text { extract }\end{array}$ & Phosphatidylcholine & Phosphatidylethanolamine & Phosphatidylinositol & Triacylglycerol & $\begin{array}{l}\text { Free fatty } \\
\text { acids }\end{array}$ \\
\hline & \multicolumn{6}{|c|}{$\mathrm{cpm} \times 10^{-3} / \mathrm{mg}$ protein } \\
\hline Control & $870 \pm 10$ & $333 \pm 15$ & $216 \pm 8$ & $9 \pm 3$ & $2 \pm 2$ & $20 \pm 1$ \\
\hline Iodoacetate & $836 \pm 13$ & $279 \pm 10^{*}$ & $166 \pm 7^{*}$ & $37 \pm 2^{*}$ & $28 \pm 1$ & $183 \pm 3^{*}$ \\
\hline Iodoacetate + U26,384 & $821 \pm 19$ & $380 \pm 12$ & $240 \pm 4$ & $36 \pm 1^{*}$ & $21 \pm 1$ & $12 \pm 1^{*}$ \\
\hline
\end{tabular}

Cultured myocardial cells were plated and labeled with $\left[{ }^{3} \mathrm{H}\right]$ arachidonate as described in Methods. After a 24-h labeling period, the radioactive medium was removed and the cells were incubated in the presence and absence of U26,384 $\left(5 \times 10^{-6} \mathrm{M}\right)$ for 90 min. The cells were then exposed to either no additions (control) or iodoacetate $(30 \mu \mathrm{M})$, for a period of $4 \mathrm{~h}$. The combined cells and medium were extracted for lipids. Aliquots of the total lipid extract were separated into various lipid classes by TLC and the spots corresponding to added internal standards were scraped and counted by liquid scintillation. It should be noted that the phosphatidylinositol fraction represents the combined [ $\left.{ }^{3} \mathrm{H}\right]$ arachidonate content of the phosphatidylinositol and phosphatidylserine species. Recovery of $\left[{ }^{3} \mathrm{H}\right]$ arachidonate exceeded $95 \%$. The data are expressed as mean \pm SEM for $n=3$ or greater. * $P<0.05$ vs. control. 
cultured myocardial cells with U26,384 $\left(5 \times 10^{-6} \mathrm{M}\right)$ for 90 min reduced the release of $\left[{ }^{3} \mathrm{H}\right]$ arachidonic acid from phosphatidylcholine and phosphatidylethanolamine (Table I) and the accumulation of radiolabeled arachidonic acid after treatment with iodoacetate (Fig. 2). The effects of U26,384 were dose dependent with an $\mathrm{IC}_{50}$ of $1-5 \times 10^{-6} \mathrm{M}$. No effects were noted with the vehicle (ethyl alcohol) for delivery of U26,384. During these studies, there was a $>95 \%$ recovery of the radiolabel throughout the extraction and chromatographic procedures. Thus, pretreatment of myocardial cells with the synthetic phospholipase inhibitor, U26,384, prevented the elevated release of labeled arachidonic acid from the cultured myocardial cells during ATP depletion, which was observed without the drug. Pretreatment with U26,384 alone had no significant effect on the baseline release of $\left[{ }^{3} \mathrm{H}\right]$ arachidonic acid from control myocardial cells.

Effects of U26,384 on the degradation of phosphatidylcholine. To further document the effects of U26,384 on phospholipid degradation during myocardial cell injury, myocardial cells were labeled with $\left[{ }^{14} \mathrm{C}\right]$ choline for $24 \mathrm{~h}$ (Table II). As shown in Table II, the cells achieved maximal incorporation of $\left[{ }^{14} \mathrm{C}\right]$ choline into phosphatidylcholine by $16 \mathrm{~h}$, at which time the specific activity of $\left[{ }^{14} \mathrm{C}\right]$ phosphatidylcholine reached equilibrium and remained constant for $20 \mathrm{~h}$. Treatment with iodoacetate for 3-4 h resulted in a $20 \%$ decrease in the $\left[{ }^{14} \mathrm{C}\right]-$ phosphatidylcholine content of the myocytes (Table III). The decrease in $\left[{ }^{14} \mathrm{C}\right]$ phosphatidylcholine content of the cells was paralleled by a concomitant two- to fourfold increase in the $\left[{ }^{14} \mathrm{C}\right]$ choline metabolites of the methanol-water-soluble fraction of the medium (Table IV). Since the specific activity of $\left[{ }^{14} \mathrm{C}\right]$ phosphatidylcholine was unchanged after treatment with iodoacetate (control 17,360 $\pm 1,071$; iodoacetate, 17,823 \pm 806 ; $\mathrm{cpm} / \mu \mathrm{gPi})$, the decrease in $\left[{ }^{14} \mathrm{C}\right]$ phosphatidylcholine content accurately reflected a similar decrease in the absolute level of phosphatidylcholine. Since pretreatment with U26,384 inhibited the degradation of $\left[{ }^{14} \mathrm{C}\right]$ phosphatidylcholine (Table III), the concomitant accumulation of $\left[{ }^{14} \mathrm{C}\right]$ choline metabolites (Table IV), and the increases in $\left[{ }^{3} \mathrm{H}\right]$ arachidonic acid release indicate that phosphatidylcholine degradation and the accumulation of free arachidonic acid are coupled in this model.

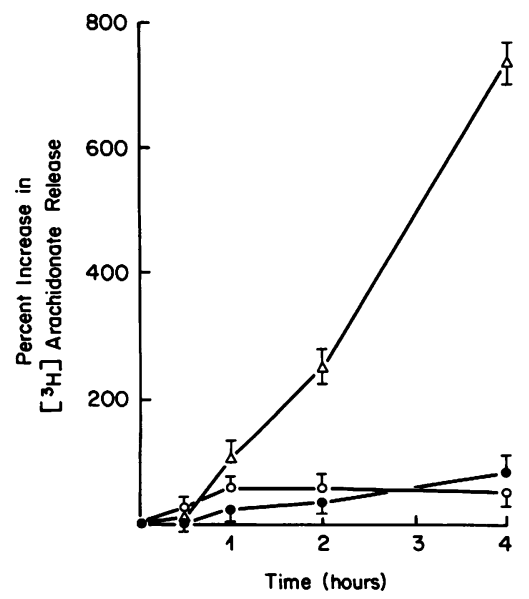

Figure 2. Effect of U26,384 on the time course of the release of $\left[{ }^{3} \mathrm{H}\right]$ arachidonic acid from cultured myocardial cells during ATP depletion. Cultured myocardial cells were grown to confluency and labeled with $\left[{ }^{3} \mathrm{H}\right]-$ arachidonate for $24 \mathrm{~h}$. The radioactive medium was subsequently removed and replaced with fresh medium with or without U26,384.

Subsequently, the cells

were exposed to either no additions (control) or iodoacetate $(30 \mu \mathrm{M})$. After various time periods, the medium was removed and the $\left[{ }^{3} \mathrm{H}\right]-$ arachidonate content was assessed as described in Methods. Results are expressed as the mean \pm SEM for $n=3$ or more experiments. (o) Control; (•) U26,384 + iodoacetate; $(\Delta)$ iodoacetate alone.
Table II. Equilibrium Labeling of Phosphatidylcholine with $\left[{ }^{14} \mathrm{C}\right]$ Choline in Cultured Myocardial Cells

\begin{tabular}{cccc}
\hline $\begin{array}{c}\text { Duration } \\
\text { of labeling }\end{array}$ & $\begin{array}{c}\left.{ }^{14} \mathrm{C}\right]- \\
\text { Phosphatidylcholine }\end{array}$ & $\begin{array}{c}\text { Phosphatidylcholine } \\
\text { content }\end{array}$ & $\begin{array}{c}\text { Phosphatidylcholine } \\
\text { specific activity }\end{array}$ \\
\hline$h$ & $c p m$ & $\mu g$ & $c p m / \mu g$ \\
4 & $65,535 \pm 2,103$ & $19.0 \pm 0.8$ & $3,440 \pm 110$ \\
8 & $137,130 \pm 3,672$ & $17.8 \pm 1.2$ & $7,699 \pm 380$ \\
16 & $341,580 \pm 8,166$ & $19.3 \pm 1.0$ & $17,744 \pm 779$ \\
24 & $403,650 \pm 7,589$ & $24.9 \pm 1.7$ & $16,223 \pm 121$ \\
36 & $409,875 \pm 8,208$ & $22.7 \pm 1.6$ & $18,024 \pm 187$ \\
& & & \\
\hline
\end{tabular}

Cultured myocardial cells were labeled with $\left[{ }^{14} \mathrm{C}\right]$ choline for various time periods. Myocardial cell lipids were extracted and phosphatidylcholine was separated as described in Methods. Aliquots of the phosphatidylcholine fraction were taken for phosphate analysis and for assessment of radioactivity. Results represent the counts per minute and phosphate content of a 50- $\mu$ l aliquot of the phosphatidylcholine fraction. The data are expressed as mean \pm SEM for $n=3$ or greater.

Effects of U26,384 on sarcolemmal membrane defects. Previous studies using this cultured cell model have demonstrated a close relationship between the release of radiolabeled arachidonic acid from membrane phospholipids and the development of sarcolemmal permeability defects (7). Comparison of Figs. 2 and 3, reveals a temporal relationship between the release of creatine kinase from the myocardial cells and the accumulation of radiolabeled arachidonic acid in the extracellular medium. The $50 \%$ increase in creatine kinase release after $1 \mathrm{~h}$ of iodoacetate treatment may reflect the release of creatine kinase from reversibly injured myocardial cells, as has been previously reported (15). However, arachidonate release also began at $1 \mathrm{~h}$, which suggests that some myocytes had become severely injured at that time point. Pretreatment with U26,384 resulted in protection against the release of creatine

Table III. Effect of U26,384 on the $\left[{ }^{14} \mathrm{C}\right]$ Phosphatidylcholine Content after Treatment with Iodoacetate

\begin{tabular}{cclc}
\hline Time & Control & Iodoacetate & $\begin{array}{r}\text { Iodoacetate } \\
+ \text { U26,384 }\end{array}$ \\
\hline$h$ & & & \\
1 & $2,071 \pm 43$ & $2,027 \pm 73$ & - \\
2 & $2,105 \pm 79$ & $2,015 \pm 58$ & - \\
3 & $2,073 \pm 67$ & $1,687 \pm 103^{*}$ & - \\
4 & $1,985 \pm 128$ & $1,589 \pm 83^{*}$ & $1,894 \pm 147$
\end{tabular}

Cultured myocardial cells were equilibrium labeled with $\left[{ }^{14} \mathrm{C}\right]$ choline for $24 \mathrm{~h}$, pretreated for $90 \mathrm{~min}$ in the presence and absence of $\mathrm{U} 26,384\left(5 \times 10^{-6} \mathrm{M}\right)$, and divided into control and treated groups (100 $\mu \mathrm{M}$ iodoacetate) as described in Methods. After various time periods, the myocardial cells and extracellular medium were harvested for the assessment of $\left[{ }^{14} \mathrm{C}\right]$ choline content of both the lipid and methanol water-soluble fractions. Separation of lipid and water soluble metabolites was performed as described in Methods. Results are expressed as $\mathrm{cpm} \times 10^{-2} / \mathrm{mg}$ protein and represent the mean \pm SEM for $n=3$ or greater.

${ }^{*} P<0.05$ vs. initial control values. 
Table IV. Effects of U26,384 on the Loss of $\left[{ }^{14} \mathrm{C}\right]$ Choline Lipids and the Accumulation of Methanol-Water Soluble $\left[{ }^{14} \mathrm{C}\right]$ Choline Metabolites after Treatment with Iodoacetate for $4 h$

\begin{tabular}{lccccc}
\hline & \multicolumn{2}{c}{ Cell } & \multicolumn{2}{c}{ Medium } \\
\cline { 2 - 5 } \cline { 5 - 5 } & Lipid extract & $\begin{array}{c}\text { Water soluble } \\
\text { extract }\end{array}$ & Lipid extract & $\begin{array}{c}\text { Water soluble } \\
\text { extract }\end{array}$ \\
\hline $\begin{array}{l}\text { Control } \\
\begin{array}{l}\text { Iodoacetate } \\
\text { Iodoacetate } \\
+ \text { U26,384 }\end{array}\end{array}$ & $3,063 \pm 171$ & $415 \pm 14$ & $17 \pm 2$ & $211 \pm 32$ \\
& $3,740 \pm 183$ & $122 \pm 6^{\ddagger}$ & $31 \pm 2^{\ddagger}$ & $876 \pm 22^{\ddagger}$ \\
\hline
\end{tabular}

Experimental details are identical to those described in Table III, except that the lipid and methanol/ $\mathrm{H}_{2} \mathrm{O}$ fractions of both the cells and extracellular medium were harvested for $\left[{ }^{14} \mathrm{C}\right]$ choline activity. The results are expressed as the mean \pm SEM of three separate experiments, each containing triplicate plates of myocardial cells (cpm $\times 10^{-2} / \mathrm{mg}$ protein): ${ }^{*} P<0.05$ vs. control, ${ }^{\ddagger} P<0.05$ vs. $\mathrm{U} 26,384$ treated.

kinase into the extracellular medium. The $\mathrm{IC}_{50}$ for the inhibition of creatine kinase release paralleled the $\mathrm{IC}_{50}$ for inhibition of $\left[{ }^{3} \mathrm{H}\right]$ arachidonic acid release $(1-5 \mu \mathrm{M})$. Thus, the ability of the drug to inhibit phospholipid degradation and arachidonic acid release correlated with the inhibition of creatine kinase release in a time- and dose-dependent manner. This result is consistent with recent experiments that have demonstrated a protective effect of $\mathrm{U} 26,384$ on the accumulation of myocardial cell $\mathrm{Ca}^{++}$during ATP depletion (16).

As depicted in Table $\mathrm{V}$, the protective effect of $\mathrm{U} 26,384$ cannot be ascribed to inhibition of the rate or extent of ATP depletion after treatment with iodoacetate. The myocardial cell ATP content decreased in a time-dependent and parallel fashion in both the U26,384-treated and untreated groups. At $3 \mathrm{~h}$ of iodoacetate exposure, the extent of ATP depletion in both groups exceeded an $80 \%$ decrease versus control levels, an extent of ATP depletion that correlates with arachidonic acid release and irreversible injury in this model (7-9). Thus, the protective effects of $\mathrm{U} 26,384$ are directed at the consequences

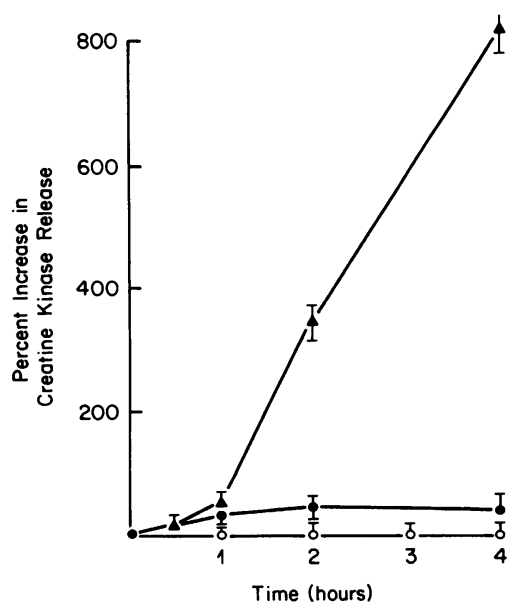

Figure 3. Effect of U26,384 on the time course of release of creatine kinase activity into the extracellular medium in cultured rat myocardial cells during ATP depletion. Experimental details are similar to those described in Fig. 2. Creatine kinase activity was assessed as described in Methods. Results are expressed as mean \pm SEM for $n=3$ or greater. (o) Control; (•) $5 \times 10^{-6} \mathrm{M}$ $\mathrm{U} 26,384+30 \mathrm{M}$ iodoacetate; (४) $30 \mu \mathrm{M}$ iodoacetate alone.
Table V. Effects of U26,384 on the Time Course of ATP Depletion after Treatment with Iodoacetate

\begin{tabular}{lccc}
\hline Time & Control & Iodoacetate & Iodoacetate + U26,384 \\
\hline \multicolumn{1}{c}{} & & & \\
0 & $31.4 \pm 2.8(9)$ & - & - \\
0.75 & - & $22.6 \pm 1.6(4)$ & $28.7 \pm 6.0(4)$ \\
1.5 & - & $21.3 \pm 3.5(4)$ & $23.1 \pm 6.1(4)$ \\
2 & - & $8.0 \pm 3.8^{*}(4)$ & $9.0 \pm 3.8^{*}(4)$ \\
3 & $37.4 \pm 2.8(4)$ & $0.9 \pm 0.8^{*}(7)$ & $5.1 \pm 1.8^{*}(8)$
\end{tabular}

Experimental details are similar to those described in Fig. 2. Values represent mean \pm SEM of $\mathrm{nmol}$ ATP/mg protein from four different experiments. The number of total culture plates is given in parentheses. ATP concentration was determined by HPLC and protein was measured by the technique of Lowry (as described in Methods). Time is expressed as hours after the introduction of $30 \mu \mathrm{M}$ iodoacetate to cultures.

* Iodoacetate and iodoacetate + U26,384 significantly different from average control value (33.2 \pm 2.2$)$, but not from each other by analysis of variance and Duncan's multiple range test.

of ATP depletion, rather than on blunting the effects of iodoacetate on myocardial cell ATP content.

The morphology of the myocardial cells was examined by light and electron microscopy after treatment with iodoacetate in the presence or absence of the phospholipase inhibitor. We have previously shown that incubation of the cultured myocytes with iodoacetate results in the time-dependent progression of cellular injury $(7,9)$. This injury reaction is detectable with both light and electron microscopy. Contraction bands develop as the cells bleb and assume a rounded rather than normal flattened shape. The myofibrillar contractile apparatus is disorganized as well as contracted and there is a loss of the characteristic sarcomere pattern. The mitochondria become spherical in shape and exhibit swollen cristae. In the late stages of injury, amorphous matrix (flocculent) densities are found in the swollen mitochondria and the sarcolemma shows anatomic defects. Pretreatment with U26,384 prevented all of these manifestations of cell injury at $4 \mathrm{~h}$ of iodoacetate treatment (Fig. 4).

\section{Discussion}

To further explore the role of phospholipid degradation and arachidonic acid release in the development of irreversible myocardial injury during ATP depletion, we have characterized the effects of a synthetic inhibitor of phospholipase activity. The potential value of such an inhibitor is twofold. First, this inhibitor allowed the direct evaluation of the role of phospholipase activation in the development of myocardial cell injury. Existing phospholipase inhibitors, such as chlorpromazine, although they show some potential for protection in selected models (17), they have failed to inhibit phospholipid degradation consistently or to prevent the development of irreversible injury during in vivo myocardial ischemia. Second, these prototype agents, or structurally related analogues, may eventually have important value in developing new agents to protect ischemic myocardium during real or threatened myocardial infarction in man. 

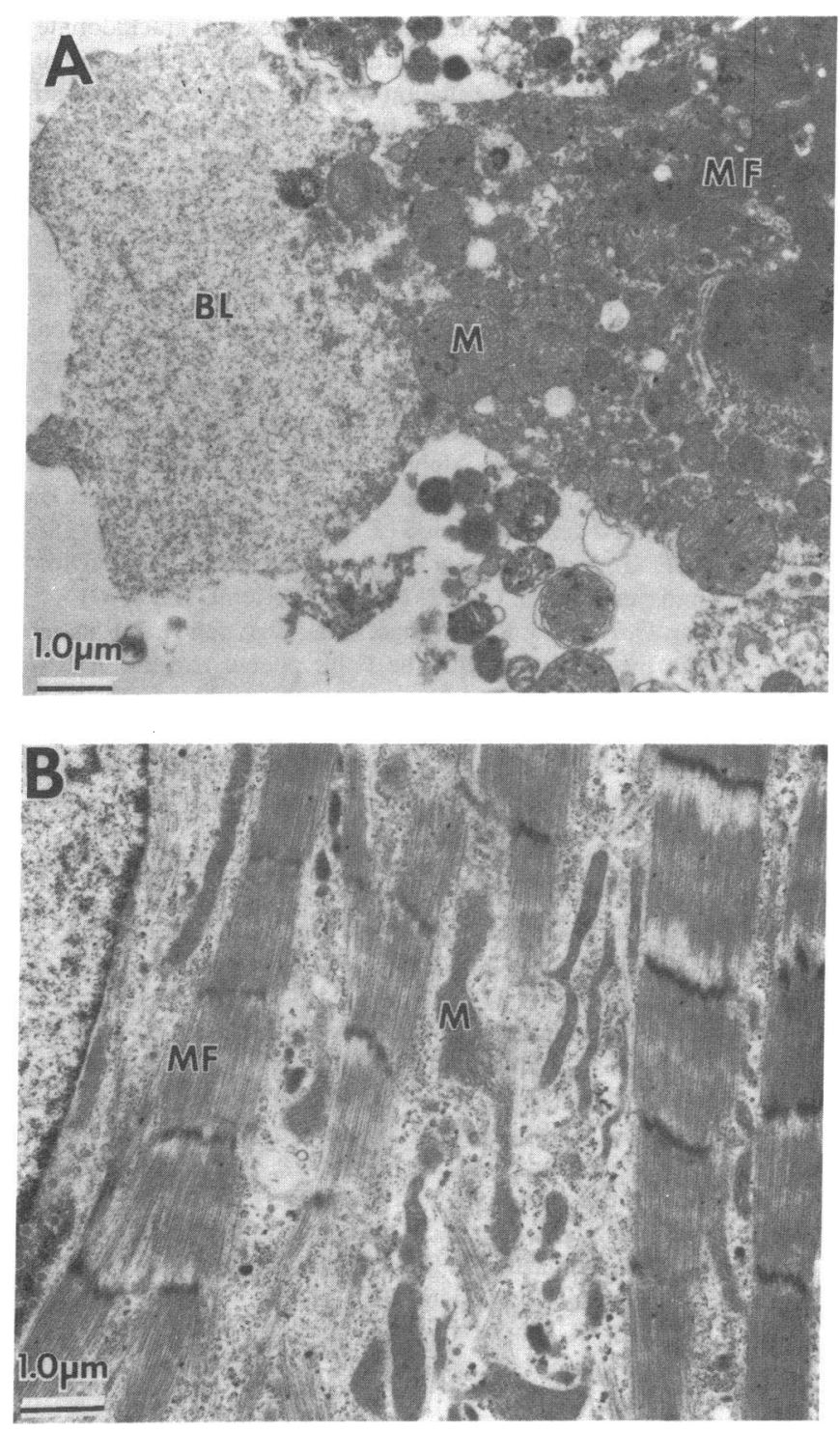

Figure 4. Electron micrographs of cultured neonatal rat myocardial cells. $(A)$ Myocyte treated with iodoacetate $(30 \mathrm{M})$ for $4 \mathrm{~h}$. The cell is severely damaged, a bleb $(B L)$ has formed and the sarcolemma is disrupted. The mitochondria $(M)$ are spherical and have dilated cristae and amorphous matrix densities. The myofibrils $(M F)$ are contracted and disorganized. $(B)$ This myocyte was treated with the phospholipase inhibitor $\mathrm{U} 26,384\left(1 \times 10^{-6} \mathrm{M}\right)$ for $90 \mathrm{~min}$ before being treated with iodoacetate $(30 \mu \mathrm{M})$ for $4 \mathrm{~h}$. This cell shows normal ultrastructure and is typical of the majority of the cells in the culture.

The present study demonstrated that a cultured myocardial cell model can be used to screen synthetic compounds that can potentially inhibit the degradation of myocardial cell phospholipids. Using this model, a compound (U26,384) has been identified that prevents the degradation of phosphatidylcholine and the release of arachidonic acid after ATP depletion. The current studies did not determine the specificity of U26,384 for individual phospholipase activities (phospholipase $A$ versus phospholipase $C$ ) and do not necessarily indicate that the effects of $\mathrm{U} 26,384$ on myocardial cells are restricted to effects on myocardial phospholipases. It should be pointed out that iodoacetate may have diverse effects on myocardial cell metabolism beyond its well known effects as a glycolytic inhibitor. Accordingly, the possibility exists that U26,384 may have other interactions with iodoacetate. To clarify this point, studies are currently examining the effect of the drug on myocardial cell viability during injury with other stimuli for myocardial cell injury. In any event, the data in this study clearly show that iodoacetate-induced alterations of membrane phospholipid metabolism are prevented by $U 26,384$, in spite of a marked decrease in ATP content, which is considered to be an important component of ischemia.

The specific biochemical mechanisms that are responsible for the liberation of free arachidonic acid during myocardial cell injury are unknown. Myocardial cells contain both phospholipase $A$ and phospholipase $C$ activities, which could contribute to the liberation of arachidonic acid from phosphatidylcholine via separate enzymatic pathways (18-20). Phospholipase A activities can directly liberate fatty acids from phosphatidylcholine, which would result in the formation of lysophosphatidylcholine. The lysophosphatidylcholine can be reacylated by lysophosphatidylcholine acyltransferase to phosphatidylcholine (21). In this manner, the liberation of arachidonic acid would not result in the net loss of the phosphatidylcholine molecule nor in the gain of free fatty acids. A similar deacylation-reacylation cycle has been demonstrated in many cell types during arachidonic acid release after the stimulation with various agonists $(22,23)$. Instead of being reacylated, the lysophosphatidylcholine molecule can be further degraded to glycerophosphorylcholine, which results in the net liberation of two free fatty acids. In addition, initial cleavage by phospholipase $\mathrm{C}$ would produce phosphocholine and diacylglycerol $(18,19)$. Subsequently, diacylglycerol and monoacylglycerol lipases can liberate fatty acids from the glycerol backbone.

To distinguish between the possible mechanisms of reacylation versus complete degradation, myocardial cells were radiolabeled with $\left[{ }^{14} \mathrm{C}\right]$ choline and the metabolic fate of potential hydrolysis products of $\left[{ }^{14} \mathrm{C}\right]$ phosphatidylcholine was examined after ATP depletion. After treatment with iodoacetate for 3-4 $\mathrm{h}$, there was a $20 \%$ decrease in the $\left[{ }^{14} \mathrm{C}\right]-$ phosphatidylcholine content of the myocytes and a corresponding increase in $\left[{ }^{14} \mathrm{C}\right]$ choline metabolites in the watersoluble fraction. Pretreatment with U26,384 blocked the liberation of arachidonic acid, the degradation of $\left[{ }^{14} \mathrm{C}\right]$ phosphatidylcholine, and the concomitant accumulation of $\left[{ }^{14} \mathrm{C}\right]$ choline metabolites. Taken together, these results indicate that the liberation of arachidonic acid from phosphatidylcholine during myocardial cell injury is coupled to the hydrolysis of the choline head group and to a net depletion of phosphatidylcholine from myocardial membranes. These results are compatible with two possibilities: $(a)$ a phospholipase $\mathrm{A}_{2}$ or phospholipase $\mathrm{C}$-initiated process followed by further degradation of lysophosphatidylcholine or diacylglycerol, respectively, or (b) a defective reacylation of arachidonic acid and other fatty acyl moieties followed by further degradation of lysophosphatidyl choline and the release of the water-soluble choline head group. Additional studies are needed to further define the role of phospholipase A and C, lysophospholipases, and the lysophosphatidylcholine-acyltransferase activities in the liberation of arachidonic acid from phosphatidylcholine during ATP depletion.

Inhibition of phospholipid degradation and arachidonic acid release prevents the development of sarcolemmal defects. Several studies have demonstrated an association between al- 
terations in phospholipid metabolism and membrane damage during myocardial cell injury $(3,6-9,24)$. However, these observations do not necessarily indicate a cause and effect relationship. The availability of a synthetic agent that blocks arachidonic acid release during myocardial cell ATP depletion allows a critical evaluation of the role of phospholipid degradation in the development of membrane damage.

This study has demonstrated that U26,384 inhibits the release of $\left[{ }^{3} \mathrm{H}\right]$ arachidonic acid and the degradation of $\left[{ }^{14} \mathrm{C}\right]-$ phosphatidylcholine, and also prevents the development of sarcolemmal defects as assessed by electron microscopy and the release of creatine kinase into the extracellular medium. Using iodoacetate as a metabolic inhibitor, it has been demonstrated that myocardial cells can withstand large decreases in cellular ATP levels without developing sarcolemmal membrane defects. Since the development of these sarcolemmal defects is a hallmark of irreversible injury $(25,26)$, these results provide additional evidence that the release of arachidonic acid is linked to the onset of irreversible injury of cultured myocardial cells during ATP depletion. However, there are several reasons for interpreting the results of the present study with caution. First, myocardial ischemia has diverse effects on myocardial cell metabolism, particularly on the redox state, in addition to the effects on the depletion of high energy phosphates. Second, the stimulus used for ATP depletion in these studies (iodoacetate) may have effects on the structure and function of myocardial cell membranes beyond the depletion of ATP. Third, it is currently unclear if the response of cultured myocardial cells can be extrapolated to the conditions of in vivo ischemia. Attempts to use U26,384 and related analogues to directly assess this relationship in intact heart models have been hampered by the low solubility of the compound in aqueous solutions. The identification of new synthetic inhibitors in this cultured cell model will be required to eventually allow the critical evaluation of the role of phospholipid degradation in the development of irreversible myocardial injury in ischemic myocardium.

\section{References}

1. Chien, K. R., J. Abrams, A. Serroni, J. T. Martin, and J. L. Farber. 1978. Accelerated phospholipid degradation and associated membrane dysfunction in irreversible ischemic liver cell injury. J. Biol. Chem. 253:4809-4817.

2. Chien, K. R., J. Abrams, R. G. Pfau, and J. L. Farber. 1977. Prevention by chlorpromazine of ischemic liver cell death. Am. J. Pathol. 88:539-558.

3. Van der Vusse, G. I., T. H. M. Roeman, F. W. Prinzen, W. A. Coumans, and R. S. Reneman. 1982. Uptake and tissue content of fatty acids in dog myocardium under normoxic and ischemic conditions. Circ. Res. 50:538-546.

4. Hsueh, W., P. C. Isaksan, and P. Needleman. 1977. Hormone selective lipase activation in the isolated rabbit heart. Prostaglandins. 13:1073-1090.

5. Weglicki, W. B. Degradation of phospholipids of myocardial membranes. In Degradative Processes in Heart and Skeletal Muscle. K. Wildenthal, editor. Elsevier/North Holland, Amsterdam. 377-388.

6. Chien, K. R., A. Sen, A. Han, L. M. Buja, and J. T. Willerson. 1985. Accumulation of unesterified arachidonic acid in ischemic canine myocardium: relationship to a phosphatidylcholine deacylationreacylation cycle and the depletion of membrane phospholipids. Circ. Res. 54:313-322.

7. Chien, K. R., A. Sen, R. Reynolds, A. Chang, Y. M. Kim, M. D.
Gunn, L. M. Buja, and J. T. Willerson. 1985. Release of arachidonate from membrane phospholipids in cultured neonatal rat myocardial cells during ATP depletion. Correlation with sarcolemmal defects and the progression of cell injury. J. Clin. Invest. 75:1770-1780.

8. Gunn, M. D., A. Sen, Y. M. Kim, J. T. Willerson, L. M. Buja, and K. R. Chien. 1985. Mechanisms of the accumulation of arachidonic acid in cultured myocardial cells during ATP depletion. Am. J. Physiol. 249:H1188-1194.

9. Buja, L. M., H. K. Hagler, D. Parsons, K. Chien, R. C. Reynolds, and J. T. Willerson. 1985. Alterations of ultrastructure and elemental composition in cultured neonatal rat cardiac myocytes after metabolic inhibition with iodoacetic acid. Lab. Invest. 53:397-412.

10. Lee, H. R., S. A. Henderson, R. Reynolds, P. Dunnmon, D. Yuan, and K. R. Chien. 1988. Alpha-1 adrenergic stimulation of cardiac gene transcription in neonatal rat myocardial cells: effect on myosin light chain-2 gene expression. J. Biol. Chem. 263:7352-7358.

11. Bligh, E. G., and E. G. Dyer. 1959. A rapid method of total lipid extraction and purification. Can. J. Biochem. Physiol. 37:911-917.

12. Lowry, O. H., N. J. Rosebrough, A. L. Farr, and R. J. Randall. 1951. Protein measurement with the Folin phenol reagent. J. Biol. Chem. 193:265-275.

13. Higgins, T. J. C., D. Allsopp, and P. J. Bailey. 1980. The effect of extracellular calcium concentration and Ca-antagonist drugs on enzyme release and production by anoxic heart cell cultures. J. Mol. Cell. Cardiol. 12:909-927.

14. Zar, J. H. 1974. Biostatistical Analysis. Prentice-Hall, Inc., Englewood Cliffs, NJ.

15. Heyndrickx, G. R., J. Amano, T. Kenna, J. T. Fallon, T. A. Patrick, W. T. Manders, G. G. Rogers, C. Rosendorff, and S. F. Vatner. 1985. Creatine kinase release is not associated with myocardial necrosis after short periods of coronary artery occlusion in conscious baboons. J. Am. Coll. Cardiol. 6:1299-1303.

16. Jones, R. L., J. C. Miller, P. K. Williams, K. R. Chien, J. T. Willerson, and L. M. Buja. 1987. The relationship between arachidonate release and calcium overloading during ATP depletion in cultured neonatal rat cardiac myocytes. Fed. Proc. 46:1152. (Abstr.)

17. Chien, K. R., J. S. Crie, R. S. Decker, and K. Wildenthal. 1983. Influence of chlorpromazine on lysosomal alterations during myocardial ischemia. Cardiol. Res. 17:407-414.

18. Corr, P. B., R. W. Gross, and B. E. Sobel. 1984. Amphipathic metabolites and membrane dysfunction in ischemic myocardium. Circ. Res. 55:135-154.

19. Hostetler, K. Y., and L. B. Hall. 1980. Phospholipase C activity of rat tissues. Biochem. Biophys. Res. Commun. 96:388-393.

20. Nalbone, G., and K. Y. Hostetler. 1985. Intracellular localization of phospholipases in rat heart: evidence for a cytosolic phospholipase $A_{1}$. J. Lipid Res. 26:104-114.

21. Gross, R. W., and B. E. Sobel. 1982. Lysophosphatidylcholine metabolism in the rabbit heart. J. Biol. Chem. 257:6702-6708.

22. Irvine, R. G. 1982. How is the level of free arachidonic acid controlled in mammalian cells? Biochem. J. 204:3-16.

23. Beaudry, G. A., L. King, L. W. Daniel, and M. Waite. 1982. Stimulation of deacylation in Madin Darby kidney cells. J. Biol. Chem. 257:10973-10977.

24. Chien, K. R., J. P. Reeves, L. M. Buja, F. Bonte, R. W. Parkey, and J. T. Willerson. 1981. Phospholipid alterations in canine ischemic myocardium. Temporal and topographical correlations with Tc-99m$\mathrm{PPi}$ accumulation and an in vitro sarcolemmal $\mathrm{Ca}^{2+}$ permeability defect. Circ. Res. 48:711-719.

25. Herdson, P. B., N. H. Sommers, and R. B. Jennings. 1963. A comparative study of the fine structure of normal and ischemic dog myocardium with special reference to early changes following temporary occlusion of a coronary artery. Am. J. Pathol. 46:367-386.

26. Burton, K. P., H. K. Hagler, G. H. Templeton, J. T. Willerson, and L. M. Buja. 1977. Lanthanum probe studies of cellular pathophysiology induced by hypoxia in isolated cardiac muscle. J. Clin. Invest. 60:1289-1302. 